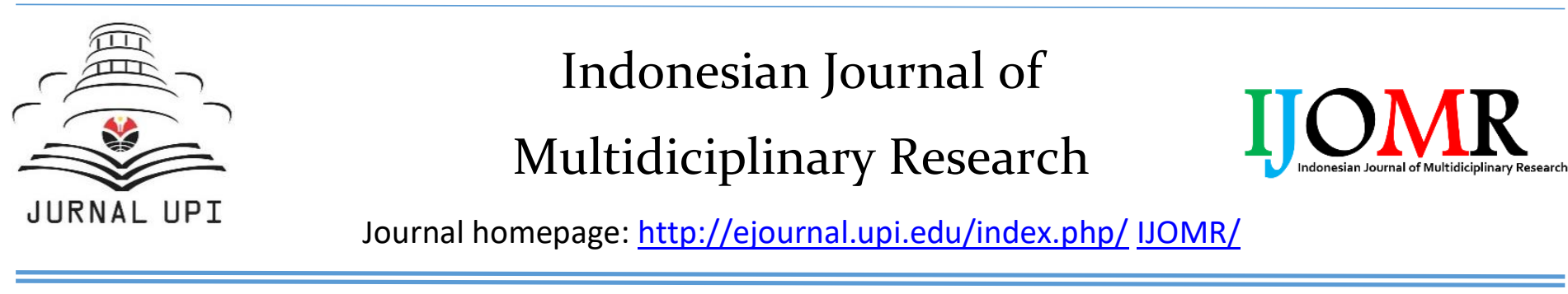

\title{
Simple Micro-hydro Uses Water as a Renewable Energy Source
}

\author{
Bunga Meilinda Putri, Listia Ningrum, Nova Masripah Maulida
}

Universitas Pendidikan Indonesia, Jl. Setiabudi No.229, Bandung, Indonesia

Correspondence: E-mail: nurul@upi.edu

\begin{abstract}
A B S T R A C T S
Fossil fuels are the main source in producing electrical energy continuously on a large scale in various countries. This will have an impact on the exhaustion of fossil fuels. Therefore, energy substitute for fossil fuels is needed. PLTMH is a renewable energy source that uses water to solve the problem of electrical energy. The purpose of this study is to determine the water discharge, the speed of water flow that comes from tap water as a source of electricity generation. Based on research in the journal, the novelty is the manufacture of power plants using simple tools to produce good and accurate research data. The research method used is literature study. Literature studies are taken from various sources that describe power generation tools using energy. From the research results in the journal, it can be seen that the higher the water discharge, the higher the mechanical efficiency of the propeller turbine. In addition, the higher the water discharge also affects the generator output power. The conclusion of this study is that the water flow that is flowed from tap water to the hose greatly affects the voltage generated, where the electric voltage will be greater if the efficiency of the turbine mechanism which acts as a mechanical energy converter and the generator output power as an electrical energy converter is high enough. The impact of the research is expected to continue to be developed and be useful as renewable energy for electrical energy problems.
\end{abstract}

\author{
ARTICLE INFO \\ Article History: \\ Submitted/Received 28 Jan 2021 \\ First revised 08 Feb 2021 \\ Accepted 09 Feb 2021 \\ First available online 11 Feb 2021 \\ Publication date 01 Mar 2021 \\ Keyword: \\ Fossil, \\ Micro-hydro. \\ Turbines and generators, \\ Renewable energy,
}




\section{INTRODUCTION}

Electricity is one of the human needs which is very important and beneficial for human activities (Suyanto \& Subandi, 2020). However, the distribution of electrical energy is still not evenly distributed, especially in remote areas that are difficult to reach by the State Electricity Company network that shown in Figure 1. PLTMH is a renewable energy power plant by utilizing endless water resources. The purpose of conducting this PLTMH study is in the context of equitable distribution of electricity needs for all communities (Gunawan, et al., 2013).

According to the Ministry of Energy and Mineral Resources on January 9, 2020, the national electricity consumption continues to increase (Grag, 2012). In 2015 the consumption was only 910 kilowatt hours (kWh) per capita. Then it increased to 1,084 kWh/capita in 2019. This increase is in line with the electrification ratio which also shows an increase. The ratio is from 84.35\% in 2014 to $98.89 \%$ in 2019. The Ministry of Energy and Mineral Resources projects that this year's national electricity consumption will reach 1,142 kWh / capita (Kurniady, 2019).

The purpose of this study was to determine the electric voltage generated from tap water using a simple micro-hydro tool by paying attention to variables such as water flow rate and the level of falling water (Martiningsih, 2019). The novelty of this tool is that PLTMh is made using simple items (used goods).

\section{METHODS}

In the preparation of this research, research methods are used that are sourced from literatures studies. The literature study takes data from previous research on hydroelectric power using propeller turbines. To make this power plant, several tools and materials are needed as follows.

1. Dinamo, as a generator producting electricity.

2. Shaft, as aliaison between the dymano and the propeller turbine.

3. Propeller turbine, as the main tool that produces rotation of the water that passes through it

4. Hose, as water circulation from the lower reservoir by means of a pump that flows to the upper reservoir unit.

5. Faucet, as an opening to drain the flow of water in order and a cover to stop the flow of water.

6. Suction pipe, as a sucker for water flow in order to produce a stable rotation.

7. Reservoir, as a reservoir for water flow from the upper reservoir through the suction pipe.

8. Pump, to move the water flow from the lower reservoir to the upper reservoir through the hose.

In research, there are several variables that will be tested as follows.

- Independent variable, namely water level.

- Controlled variables, namely, turbine, mechanical efficiency and generator output power.

- Controlled variable, namely, time (per 5 minutes)

In finding the value of the above variables, calculate the calculations and measurements. The rotation of the turbine shaft, the rotation of the connecting shaft is measured using a tachometer, the electric power of the generator and the output of the generator are 
measured using an AVO meter. Figure 2 shows the Micro-hydro prototype. Here are formulas to help process data.

$$
\begin{aligned}
& \text { Volme }=\frac{1}{4} \cdot \text { phi.r.r.t }(m) \\
& \text { Speed of water }=\frac{\text { Discharge of water }}{\text { Cross-sectional area }}(\text { meters } / \text { second }) \\
& \text { water discharge }=\frac{\text { volume }}{\text { time }}(\text { liter } / \text { second }) \\
& \text { Turbin efficiency }=\text { power coefficient } x 100 \%
\end{aligned}
$$

\section{RESULTS AND DISCUSSION}

Based on Table 1 and 2, it can be seen that the higher the air flow, the higher the turbine engine mechanics (Taba \& Allo, 2017). In addition, the higher the air flow rate also affects the generator output power as shows in Figure 3.

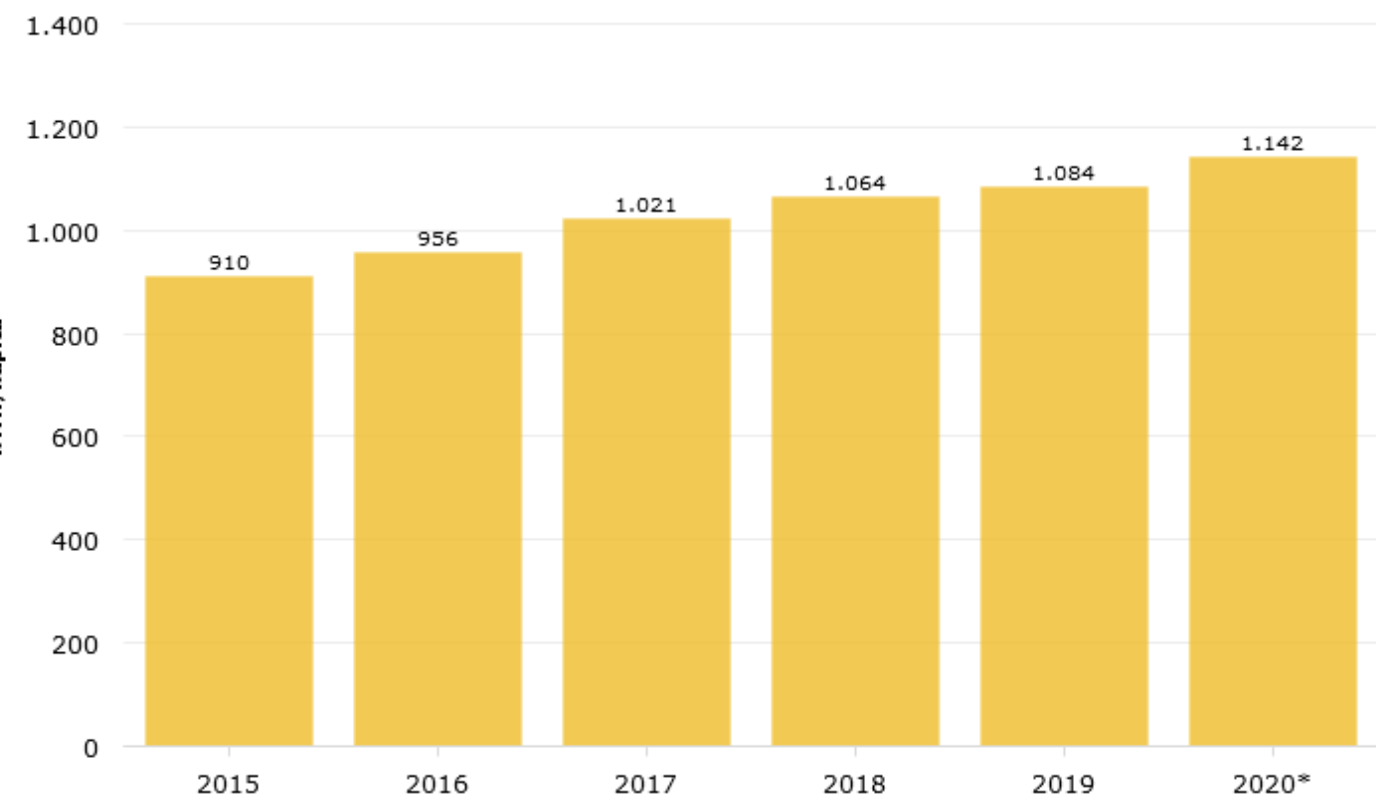

Figure 1. National electricity consumption. 


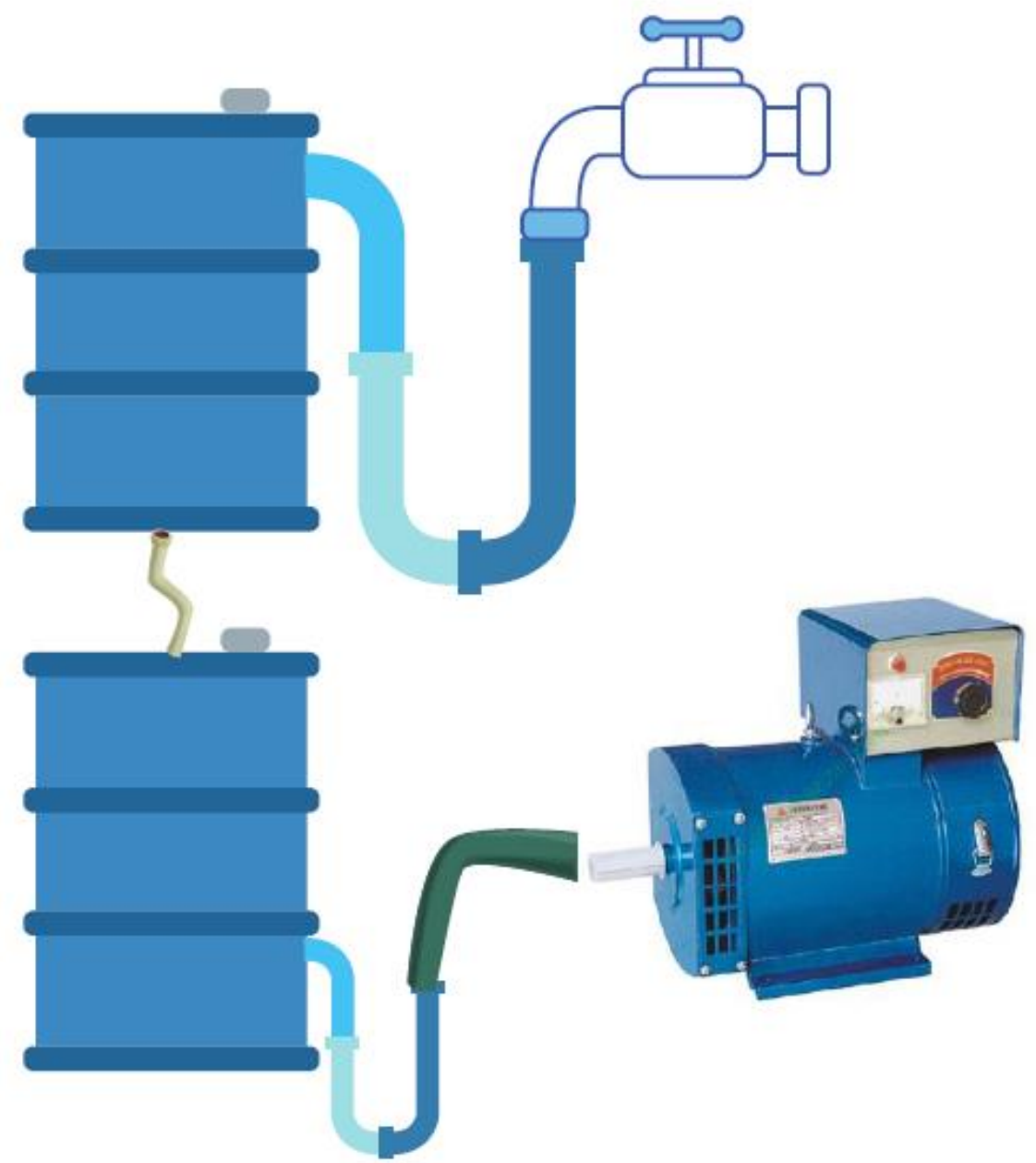

Figure 2. Micro-hydro prototype.

Table 1. Test result data.

\begin{tabular}{cccc}
\hline No. & $\begin{array}{c}\text { Time (per } \\
\text { minute) }\end{array}$ & $\begin{array}{c}\text { Water level } \\
\text { (meters) }\end{array}$ & $\begin{array}{c}\text { Ratation of the turbine } \\
\text { shaft with generator (rpm) }\end{array}$ \\
\hline $\mathbf{1 .}$ & 5 & 0,47 & 711,22 \\
$\mathbf{2 .}$ & 5 & 0,57 & 853,18 \\
$\mathbf{3 .}$ & 5 & 0,67 & 1073,00 \\
$\mathbf{4 .}$ & 5 & 0,77 & 1135,70 \\
$\mathbf{5 .}$ & 5 & 0,87 & 1314,80 \\
\hline
\end{tabular}

Table 2. Pump power.

\begin{tabular}{ccccccc}
\hline $\begin{array}{c}\text { Cross } \\
\text { sectional } \\
\text { area }\left(\mathbf{m}^{\mathbf{3}}\right)\end{array}$ & $\begin{array}{c}\text { Water } \\
\text { discharge } \\
\left(\mathbf{m}^{\mathbf{3}} \mathbf{s} \mathbf{s}\right)\end{array}$ & $\begin{array}{c}\text { Flow } \\
\text { velocity } \\
\text { power } \\
(\mathbf{m} / \mathbf{s})\end{array}$ & $\begin{array}{c}\text { Turbine } \\
\text { mechanical } \\
\text { power (watt) }\end{array}$ & $\begin{array}{c}\text { Power } \\
\text { coefficiency }\end{array}$ & $\begin{array}{c}\text { Effisiency } \\
(\%)\end{array}$ & $\begin{array}{c}\text { Generator } \\
\text { power } \\
\text { (watt) }\end{array}$ \\
\hline 0,00203 & 0,0009974 & 0,4923 & 5,7002 & 0,3348 & 33,48 & 0,403 \\
0,00203 & 0,001079 & 0,5326 & 0,5326 & 0,5326 & 0,5326 & 0,5326 \\
0,00203 & 0,001107 & 9,4316 & 9,4316 & 9,4316 & 9,4316 & 9,4316 \\
0,00203 & 0,001121 & 0,4816 & 0,4816 & 0,4816 & 0,4816 & 0,4816 \\
0,00203 & 0,00119 & 48,16 & 48,16 & 48,16 & 48,16 & 48,16 \\
\hline
\end{tabular}




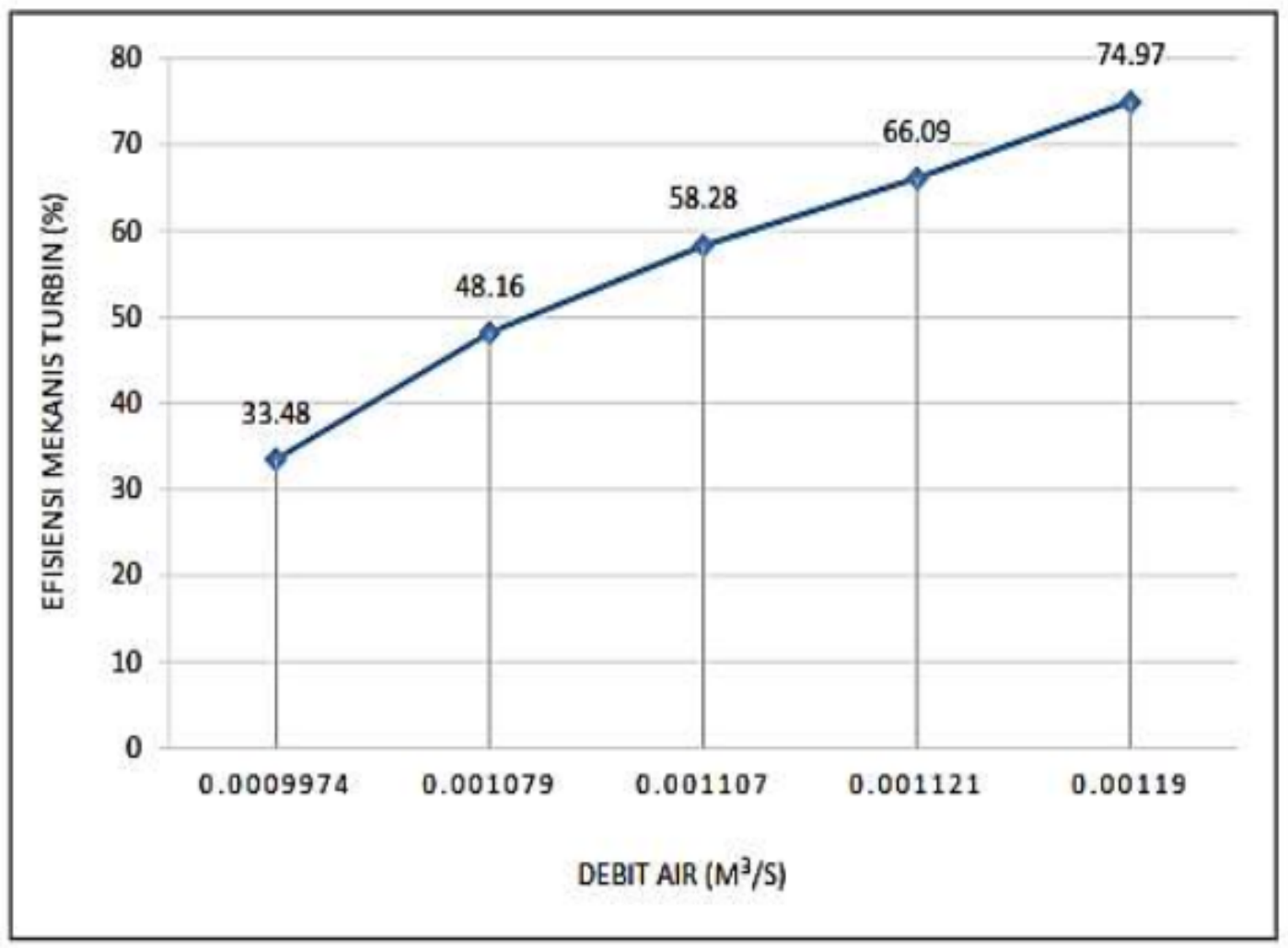

Figure 3. Graph of turbine mechanical efficiency on water discharge.

\section{CONCLUSION}

The conclusion of this study is that the water flow that is flowed from tap water to the hose greatly affects the voltage generated, where the electric voltage will be greater if the efficiency of the turbine mechanism which acts as a mechanical energy converter and the generator output power as a converter of electrical energy is high enough.

\section{ACKNOWLEDGEMENTS}

We would like to thank Mr. M. Nurul Hana, M.Pd and Mr. Dr. Eka Cahya who has provided criticism, suggestions, and motivation in the implementation of this activity. We would like to thank all those who have carried out research and made research journals as a reference in re-developing research that has been successfully carried out.

\section{AUTHORS' NOTE}

The authors declare that there is no conflict of interest regarding the publication of this article. Authors confirmed that the paper was free of plagiarism.

\section{REFERENCES}

Garg, P. (2012). Energy scenario and vision 2020 in India. Journal of Sustainable Energy and Environment, 3(1), 7-17.

Gunawan, A., Oktafeni, A., and Khabzli, W. (2013). Pemantauan pembangkit listrik tenaga 
mikrohidro. Jurnal Rekayasa Elektrika. 10(4), 202-206.

Kurniady, I., Amirsyam., and Amrinsyah. (2019). Kapasitas aliran terhadap daya turbin. Jurnal of Electrical and System Control Engineering. 2(2), 98-115.

Martiningsih, W., Herudin., and Rifa'I, A. B. (2019). Potensi pembangkit listrik tenaga mikrohidro di sungai ciliman kabupaten pandeglang. Jurnal Teknik Mesin Untirta. 5(1), 113-119.

Suyanto, M., and Subandi. (2020). Memanfaatkan Irigasi sebagai sumber energi listrik mikrohidro di Singosaren Wukirsari Bantul Yogyakarta. Jurnal Pengabdian Masyarakat. 1(2), 56-64.

Taba, H. H.T., and Allo, C. P. K. (2017). Analisa pembangkit listrik tenaga air dengan memanfaatkan turbin propeller pada laboratorium produksi teknik mesin USTJ. Jurnal Teknik Mesin. 6(1), 1-9. 